\section{Integrity as a Personal, Professional and Moral Value}

\author{
Mariana CALANCEA ${ }^{1}$ \\ ${ }^{1}$ MA, Faculty of Law and Administrative \\ Sciences, "Ştefan cel Mare" University \\ from Suceava, Romania.
}

\begin{abstract}
Integrity is a concept that encompasses a series of human values, often defined as an attribute of being and remaining honest, fair, and incorruptible. Thus, it can be assimilated to the sense of justice, dignity and conscientiousness, serving as a guide in human conduct. In the 21 st century, debates about integrity have become more and more frequent, recognizing that integrity can be appreciated as a standard to assess the conduct of a person, institution, organization or even an entire community or nation. Currently, integrity is the most effective standard when it comes to establishing the level of trust, professionalism and competence. This article theoretically addresses the way in which integrity can become a value that can only develop in an environment in which human dignity is valued, individuals enjoy the right to assert their choices and have the freedom to make choices, an environment in which justice, truth and ethical conscientiousness are unanimously accepted ethical values. However, paradoxically, integrity is highlighted only by reference to a climate or a specific situation where this value is less recognized or respected.
\end{abstract}

Keywords: Integrity; ethical values; personal integrity; professional integrity; moral integrity.

How to cite: Calancea, M. (2019). Integrity as a Personal, Professional and Moral Value. Journal for Ethics in Social Studies, 3(1), 22-27. doi: 10.18662/jess.19 


\section{Introducere}

Din punct de vedere etimologic, cuvântul ,integritate” îşi găseşte originea în cuvântul latin ,integer”, care înseamnă integralitate. În acest sens, integralitatea morală poate să fie descrisă ca fiind o coerenţă internă a valorilor individuale, reunind principii şi credințe cu acțiuni şi cuvinte (Cox, La Caze, \& Levine, 2017). Această coerență este adesea evidențiată în acele situații în care apar presiuni externe în vederea revizuirii propriei opinii sau acțiuni. În multe dintre aceste situații există o puternică presiune venită din partea autorităţilor, persoanelor cu care individul interacționează pe plan personal sau la locul de muncă sau a opiniei publice pentru a accepta o recomandare contrară. Presiunea externă nu trebuie să fie neapărat una negativă, poate să fie o tentație ori o oportunitate pozitivă, însă odată acceptată, va implica abandonarea acelor convingeri etice personale care conturează integritatea personală. Integritatea se manifestă prin exprimarea unei poziții personale, ce rămâne neschimbată şi mai puțin prin adaptarea şi conformarea la cerințele externe.

Pe de altă parte, integritatea nu se poate limita doar la această descriere, întrucât nu toate convingerile şi principiile pe care le promovează o persoană sunt automat concordante cu valorile dreptăţii şi probităţii. Integritatea este o valoare umană importantă în relaţia cu sinele, dar şi mai importantă în relația cu ceilalți. Orice alegere sau acțiune trebuie să aibă în vedere respectarea principiilor morale, precum şi atenția de a nu vătăma starea de bine a aproapelui, ci chiar de a-i oferi ajutor şi sprijin. Aşadar, atunci când vorbim despre ceea ce implică integritatea, un rol important în comportamentul integru îl are şi altruismul.

\section{Integritatea individuală}

Integritatea trebuie apreciată în corelație cu diverse aspecte ce țin de viaţa unei persoane. Este vorba de acele atribute ale comportamentului unei persoane care îi conturează integritatea profesională, artistică sau intelectuală. La nivel individual, integritatea dobândeşte o importanţă chiar mai mare decât etica, întrucât prin manifestările sale interioare, ea surprinde caracterul individului, mai exact acele caracteristici şi calități ce sunt considerate în mod constant ca exprimând transparență, etică, onestitate şi empatice faţă de cei din jur.

Atunci când vorbim despre integritate, aceasta se raportează la spațiul în care fiecare persoană îşi manifestă propria identitate (Williams, 1973), în rolurile de bază pe care şi le asumă în calitate de membră a unei 
comunităţi şi a tradițiilor morale specifice ale acelei comunităţi, precum şi ca subiect de drept sau ca cetățean în cadrul unei comunități politice. Integritatea privită sub aspect individual implică o serie largă de însuşiri etice recunoscute social, întrucât pentru ca o comunitate sau un grup să poată funcționa într-o manieră cât mai eficientă, este absolut necesar ca fiecare membru să poată conta pe existența unui comportament previzibil din partea celorlalți membri ai comunităţii şi pe respectarea rolului fiecăruia, în vederea îndeplinirii scopurilor comune.

Integritatea nu poate fi catalogată doar ca o trăsătură de caracter sau o calitate pe care o poate avea o persoană sau o organizație, ci ține inclusiv de eficiența cu care funcționează grupurile sociale, întrucât un grup poate funcționa eficient doar atunci când memmbrii care îl alcătuiesc sunt dispuşi să respecte mereu aceleaşi valori considerate de toți ca fiind importante şi să işsi direcționeze toate eforturile în vederea respectării promisiunilor sociale asumate public. In cadrul unui asemenea model, integritatea devine fundamentul conducerii eficiente şi de succes, implicând un echilibru atent între responsabilitate şi respect, care conduc la un climat de echitate şi egalitate.

A învăţa şi a înţelege respectarea convingerilor şi opiniilor altor indivizi constituie o altă formă pe care o poate lua integritatea. Din acest punct de vedere, se poate vorbi de o loialitate fără compromisuri pentru propriile convingeri în raport cu judecata unei alte persoane, opiniile şi valorile sale.

Un individ integru este dispus să accepte şi să suporte consecințele pe care le provoacă convingerile sale, chiar şi atunci când acestea nu îi aduc o stare de bine. Integritatea este principala calitate a unei persoane atunci când este creditată de cei din jur cu atribute precum stabilitatea şi siguranța. În cadrul relațiilor profesionale, cinstea şi corectitudinea sunt considerate valori de importanță deosebită, adesea mai presus decât competenţa şi cunoştințele, întrucât integritatea îmbină calitățile umane cu cele profesionale. De asemenea, în relaţiile personale, conştient sau inconştient, oamenii tind să îşi apropie persoane care prezintă garanţii de încredere, sinceritate, care îşi construiesc viaţa pe baza unor principii solide şi de la care se abat cu greu.

Alegerea de a iniția o relație cu o persoană care nu se bucură de o repuație de bună integritate sau care nu a demonstrat niciodată ca ar valorifica cu adevărat anumite principii de moralitate ar conduce în mod automat la o relație imprevizibilă şi supusă permanent amenințării. Integritatea se manifestă atât ca formă de stabilitate si incoruptibilitate, cât şi ca manieră de interrelaționare cu cei din jur. O persoană integră nu va incerca doar să nu se abată de la propriile convingeri, ci va urmări 
întotdeauna ca acțiunile sale să nu producă vreo vătămare celuilalt, să fie solidară cu nevoile celor din jur (Apostu, 2016).

Integritatea este o virtute pe care omul o învață prin educație (Calhoun, 1995). În funcție de experiența pe care o cunoaşte de-a lungul vieții, precum şi în funcție de cunoştințele pe care le cultivă, el ajunge să iş̧i formeze un set de valori, care să îi fie ghid în luarea oricărei decizii, precum şi în modul de raportare la ceilalți. Lipsa integrităţii celorlalţi membri ai comunităţii este una dintre primele lecții de moralitate deprinse în timpul etapei de socializare inițială, primară, întrucât atunci individul intră în contact cu primele exemple ale efectelor pe care le produc acțiunile necinstite şi corupte. Tocmai pe baza acestui fond, cel care observă, analizează şi experimentează aceste efecte cunoaşte empiric importanţa integrităţii şi necesitatea de a valoriza adevărul, dreptatea şi stabilitatea.

\section{Integritatea profesională}

Integritatea profesională este forma de integritate cea mai intens dezbătută în prezent, atât în mediile profesionale juridice şi politice, în massmedia, cât şi în conversațiile comune din cadrul societății. Integritatea profesională presupune a atinge un echilibru între maniera în care persoana afişează integritatea personală în mediul profesional şi felul în care controlează dorința de a-şi satisface interesele private atunci când acestea devin contrare intereselor şi principiilor organizaţiei pe care o reprezintă.

Cele mai mari dileme etice apar atunci când activitatea profesională este una parțial distinctă sau chiar contrară prin comparație cu principiile şi credințele personale. Într-o primă abordare, s-ar putea susține delimitarea convingerilor personale de cele profesionale, pornind de la ipoteza că urmarea unui stil de viață integru în spațiul personal nu ar fi afectat deloc de activitatea de la locul de muncă. Această dihotomie ar da naştere, însă, la compromisuri, ceea ce ar afecta unele dintre efectele integrităţii, cu ar fi stabilitatea şi fermitatea. În plus, un mediu de muncă în care încălcarea principiilor morale devine un obicei face imposibil ca aceste situații să nu producă efecte şi în viața personală. $\mathrm{O}$ altă opțiune ar fi respectarea unei conduite integre atât în viaţa personală, cât şi în cea profesională, întrucât nicio organizație sau afacere nu poate avea un scop ilicit, imoral sau nelegitim, fapt ce susține ideea că acțiunile şi activitățile ce trebuie întreprinse în cadrul acestei organizații trebuie să urmărească principiile etice specifice. Aşadar, ideea că lipsa integrității în mediul profesional poate conduce mai uşor la succes este combătută de realitatea că pentru a fi considerată un partener valoros, orice organizație are nevoie de o reputaţie de probitate şi 
corectitudine. În mediul profesional, imaginea publică este cea care asigură dezvoltarea şi continuitatea oricărui proiect, întocmai ca şi dobândirea respectului unei persoane în societate.

La nivel etatic, imaginea funcționarului public este principalul element care dă măsura integrității. Începând de la reprezentanții sistemului de guvernare şi continuând cu toţi ceilalţi angajaţi din sectorul public, onestitatea şi incoruptibilitatea sunt absolut indispensabile, întrucât se aşteaptă de la funcționarul public ca, prin activitatea sa, să apere şi să servească interesul general al cetățenilor.

Integritatea profesională se referă şi la activităţile pe care o persoană le întreprinde în vederea promovării funcției sale. Este absolut firesc ca oricine să îşi creeze obiective şi idealuri la care să tindă, atât în plan personal, cât şi profesional. A fi integru înseamnă a obține o performanţă doar prin propriile performanțe şi abilități, în cadrul oferit de activitatea strict profesională. Integritatea profesională este, însă, doar o subcategorie a integrității individuale. Atunci când activitatea de la locul de muncă vine în contradicție $\mathrm{cu}$ principiile asumate în viața personală sau este în afara acestora, persoana care acționează la locul de muncă contrar valorilor proprii nu se mai percepe pe sine ca fiind cinstită şi integră, stabilă şi fermă în decizii şi alegeri. Integritatea unui individ este definită ca suma tuturor acţiunilor sale, în orice plan al vieții sale şi în raport cu orice persoană.

\section{Integritatea morală}

Se ridică întrebarea dacă integritatea se limitează la a urma o viaţă bazată pe anumite principii ferme, de la care să nu existe abatere indiferent de influențele exterioare. Moralitatea este cea care ghidează adoptarea valorilor pe care individul înţelege să le respecte. Principii constante şi ferme pot fi şi cele care au la bază dorința de răzbunare, rasismul, lipsa de toleranță sau egocentrismul, însă acestea nu sunt privite, totuşi, ca şi atribute ale integrităţii sau ale moralităţii. Uneori, lipsa de flexibilitate poate avea acelaşi efect cu al lipsei de integritate, fie că este privită ca lipsă de empatie sau ca un veritabil abuz de drept (Ignătescu, 2013).

Dificultatea şi complexitatea respectării unei vieți integre nu se datorează, de cele mai multe ori, lipsei statorniciei şi fermităţii la nivel individual, ci faptului că integritatea nu serveşte atingerii scopurilor personale, ci serverşte interesele societății în ansamblul său şi vizează binele general. Integritatea impune inclusiv responsabilitate intelectuală, în vederea înțelegerii cerințelor unei conduite integre. O persoană integră îmbrăţişează o viziune morală, marcată de claritate conceptuală, consecvență logică, bazată 
pe dovezi relevante. O astfel de persoană îşi va impune singură restricțiile care îi asigură comportamentul integru, întrucât este preocupată de adoptarea unei poziții morale, dar mai ales de urmărirea unui angajament de a face ceea ce este necesar şi oportun în context general, social (Korsgaard, 2009). Corelativ, cu cât se urmăreşte şi se atinge un nivel de moralitate mai ridicat, cu atât înțelegerea şi practicarea integrității devine mai accesibilă.

\section{Concluzii}

Integritatea, privită prin raportare la valorile morale acceptate social (Sandu, 2018), nu trebuie considerată la nivel absolut, întucât aprecierea unui comportament ca fiind integru depinde de situația concretă în care se află persoana, uneori compromisul putând fi o expresie a integrității, dacă are la bază dorința de a servi interesului general, deşi din punct de vedere teoretic compromisul contravine definiției integrității.

Înțelegând conceptul de responsabilitate, înţelege şi conceptul de integritate. Legătura dintre integritate şi responsabilitate poate fi cel mai bine descrisă prin raportul ce există între ceea ce spunem şi ceea ce facem. Odată exprimată o promisiune publică, ia naştere nevoia de responsabilitate, iar nerespectarea promisiunii publice este privită ca fiind o lipsă de integritate.

\section{References}

Apostu, I. (2016). Postmodernity and the solidarity Dilemma-a challenge for the contemporary couple. Postmodern Openings, 7(2), 9-12. doi:10.18662/po/2016.0702.01

Calhoun, C. (1995). Standing for something. Journal of Philosophy, 92(5), 235-260. doi:10.2307/2940917

Cox, D., La Caze, M., \& Levine, M. (2017). Integrity. In E. N. Zalta (Ed.), The Stanford Encyclopedia of Philosophy. Retrieved from https://plato.stanford.edu/archives/spr2017/entries/integrity/

Ignătescu, C. (2013). Abuzul de drept [Abuse of rights]. Iaşi, Romania: Lumen.

Korsgaard, C. M. (2009). Self-constitution: Agency, identity, and integrity. Oxford, UK: Oxford University Press.

Sandu, A. (2018). Elemente de etică şi deontologie profesională pentru profesiile juridice și din administrația publică. Suport de curs [Elements of professional ethics and deontology for legal professions and public administration. University handbook]. Suceava, Romania: „SStefan cel Mare” University from Suceava.

Williams, B. (1973). Integrity. In J. J. C. Smart \& B. Williams, Utilitarianism: For and against (pp. 108-117). New York, USA: Cambridge University Press. 